\title{
Symbol and Symbolism in Sacred Poetry
}

\author{
Hojjatollah.ghe.Moniri' ${ }^{1}$, Nushin Dohniyatkar ${ }^{2}$ \\ ${ }^{1}$ Assistant Professor, Department of Literature, Islamic Azad University, Borujerd Branch, \\ Lorestan, Iran \\ ${ }^{2}$ M. A., Department of Literature, Islamic Azad University, Borujerd Branch, Lorestan, Iran
}

Received: 24 October 2018, Revised: 05 December 2018, Accepted: 20 December 2018

\begin{abstract}
Symbolism has been widely present in modern literature and poetry including the poetry after revolution. However, different poets have used symbolism, this magic element of literary imagination, in various ways and there are no exact researches related to symbolism. So, the present researcher decided to present the image of poetry of revolution and this way, investigated the amount of creativity and innovation of the poets in this period of time. The present research investigates the symbols and symbolism in terms of meaning and context. Some poets such as Hamid Sabzevari, Mohammad Ali Damghani and Ali Mousavi Garmaroodi have shown the national and myths symbols in terms of historical patterns specially history of sacred war period. Other poets such as Nasorallah Mardani, Alireza Ghazve, Abdull Jabar Kkaie, Gheysar Aminpour, Parviz Beigi habib abadi and Fateme Rakeiee have widely used symbols of mystic literary, and entered the emotional aspects of war and investigated its reflection in cultural space of the society. Some people like Ahmad Azizi and Bidelvare have used the symbols in their piece and finally someone like Seyed Hasan Hosseini have shown a different style by employing symbols as irony.
\end{abstract}

Keywords: Symbols, Symbolism, the Poetry of Sacred War Period.

\section{Introduction}

Symbols are one of the most significant imaginary tools from the beginning of Persian poetry especially in Eraghi period (by the emergence of mystic literature) and always had a significant and defining role. This role has been significant in modern age due to being affected by symbolism and Surrealism schools (which considered directness and clarity opposite of beauty and attractiveness of art) and obligation of the poets in using ambiguity and because of political obstruction before revolution.
The poetry of Revolution and specially "poetry of Sacred war", although came out of the censorship, due to staying away from slogans and superficiality, will continue its way after a short time and use poetical technique including symbols and symbolism. Poetic symbols of revolution are mostly general based on normal division by the scholars and poets and are categorized as follows based on meaning and context: national symbols, international symbols, religious symbols, 
political symbols and finally literary symbols.

The motives of revolution poets are related to the aforementioned symbols, political condition and objectives of revolution. What revives the national symbols (historical and myths) was a sudden calenture of national and patriarchic emotions due to confronting with enemies. At the same time, the slogan of freeing "Quds" from Zionist occupation has made the poets to pay attention to the national and international symbols.

The presence of religious and mystic symbols due to ideological and religious origin of revolution and focused on the belief constructs such as: theism, circuit province and martyrdom. The existence of political and revolutionary symbols due to Iranian opposition to West and return to their own Islamic and national identity and finally encroachment of poets to intelligent wealth and permutation of literary and imaginary symbols shows the amount of creativity of the poets which have same thinking schools.

\section{Discussion}

One of the features of poetry and literature after revolution and specially the poetry of sacred war is its tendency toward meaning and theme. There are a lot of sayings about this:

"Poets of our modern time are mostly free of symbolism and term-orientation. Directness, clearness and considering important issues in complete freedom is one of the main features of poetry of revolution" (Akbari, 1992).

However, these sayings do not mean that the art and poetry of revolution have been completely without techniques and have always been at surface like the poetry of Mashroote. Poetry of sacred war had its early beginning with primitive and incompatible poems by young poets but gradually used the experiences of poets with Islamic ideology and from the early 50 s, the poets like Hamid Sabzevari, Ali Moalem Damghani, Ali Mousavi Garmaroudi, Taheri Safarzade, Mohammad Ali Bahmani, Seyed Hosseini and others and found its real and proper style. It created nice and pleasant samples and made poetry of Revolution eternal.

Poets of this period, after passing imitation period, experienced a formal and technical transformation, gradually went toward different literary arrays. They used literary techniques such as personification, allusions, sensory integration, paradox, hyperbole, symmetry and tried to surpass each other by enriching their poems and willingly or unwillingly use a unified language and style which can be called "Revolution Poetry Style".

Symbol has been one of the techniques that poets have paid attention and recognized its importance and soon found that it is the most magic element of imagination.

"Symbols have always had a deep role in two areas of semantics and image creation and these two features caused efficient implementation of them in literary pieces. Poetry of resistance (Revolution) did not have any way except using various symbols in order to get free of darkness and slogans. So, the poets used symbols and combined them with cultural, religious and historical fields and closely approach symbolic style" (Bakhshoude, 2005).

As we know, literary symbols are divided into two main groups. Some consider these two groups as general and private ones (Shamisa, 1994) and others call them "hidden" and "common" symbols.

The base of above-mentioned division is in creativity of structure and simplicity or complexity of our understanding about the meaning of the symbols. But we have to 
know that creativity in choosing the symbols is not related to their construction but this creativity can be investigated from meaning and contextual aspect. So, we have to consider that the symbol is private or common. In addition, we would see that literary attractiveness of poetry of revolution in terms of symbolism is more attractive than its quality and construct. So, symbols of sacred war poetry can be divided into national, international, religious, philosophical, political and literary style and are analyzed independently.

\section{National Symbols}

National symbols are more divided into myth-national and historical-national symbols. Mythological symbols are the ancient ones which originate from ancient and prehistoric symbols. Some elements and components of national symbols can be found in ancient textbooks such as "Avesta" or historical textbooks such as "Shahname".

Incidence of war and encountering of Iranian with invading army and fully armed Iraqis caused a sudden calenture of national and patriarchic excitement in all social layers. This epic space provided a proper and exceptional condition for poets and artists of Revolution so that poets can deal with Iranian symbols and its relationship with history of sacred war and praise their Aryan people and encourage their brevity:

/ $\Lambda \mathrm{ft} \Lambda \mathrm{b}$ r $\Lambda$ di:/ /o/ / $\Lambda$ zærm/ /o/ /ræzm/ /o/ /rufæn $\Lambda$ i:/

/mærdi:/ /o/ /hænzır/, /yæni:/ /mærdumın/ / $\mathbf{r i}: \Lambda \mathrm{i}: /$

/mærd/ / mærd $\Lambda$ vi:3/ /mærd $\Lambda$ i:n/ /bə/ /mærdəst $\Lambda$ /

/væ/ /di:gær/ /zæn/ /væ/ /di:gær/ /zæn/

/mærdumə/ / $\mathrm{zz} \Lambda$ də/ /i:run/ /æz/ / $\Lambda \mathrm{ræ \int /}$ /væ/ /gərd $\Lambda$ æri:d/ /væ/ / $\Lambda$ ri:ubærzæn/

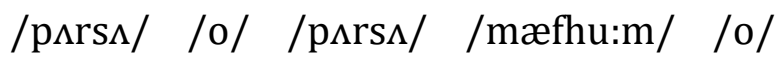
/sıdəğænd/

/məslə/ /særvu/ /o/ /særæfrızi:/ .3uft/ /nәy/ /t $\Lambda$ ğænd/

/zavdın/ /mæJhu:rə/ /æfığænd/

/kuh/ /o/ /dœryı//o/ /hımu:n/

/pırs//œz/ /œrvœnd/ /t $\Lambda$ //3әуhu:n/

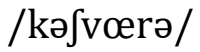
/sœlm $\Lambda$ /

/o/

/pıkın//musœlmım/ /œrsə/ /mœrdi:st/ /œrsə/ /mœrdi:st/

/sœrzœmi:n/ /məhrbıni:/ /ğœmgusıri:/ /məlkə/ /hœmdœrdi:/ /œst/

(Moallem Damghani, 1389, p.79)

National and mythological symbols present themselves in two ways: sometimes by integrating with historical and Islamic samples- which we will talk about them in their related section of religious symbols- and sometimes they are integrated with historical names specially history of war, such as:

/gœr/ /dv//ru:zi:/ /rœstəi:/ /œz/ /ti:ğg/ /ti:z/ /rustœmi:/

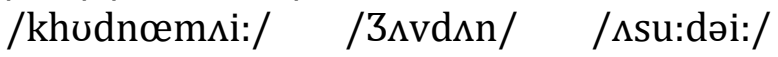
/pu:rə/ /pœjœng/

(Mousavi Gramaroudi, 2010)

In above mentioned line, the poet considers Rustam as a symbol of "last leader of the Revolution" and Afrasiab as symbol of "Saddam". In following line, "Khuzestan" and people of that city are introduced because of brevity in war of present epic mythology. These myths are symmetrical with ancient myths in terms of creating surprise.

/fəsınə/ /gœfto/ /kuhœn/ /уıdə/ /rustœmə/ /dœstın/

/œz/ /ın/ /hœmısə/ /kə/ /bı/ /khu:n/ /suru:d/ /khuzəstın/

(Sabzevari, 2009, p.131)

Sometimes this confronting is shown for challenging the intellectuals and is shown with irony: / mœn/ nəmi:/ /fœhmœm/ /hi:tf/ /rustœmə/ /vıdi:/ /muzu:n/ /tœbə^n/ 
/ kə/ /pœri:ru:z/ /zə/ /mœrdınəgi:/ /o/ /dœrd/ /həkıyœt/ /mi:kœrd/

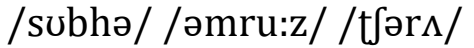

/zəmnə/ /t $\Lambda$ b $\Lambda$ ndœn//sœblœt//dœr/ /dœst/

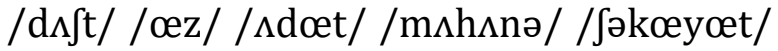
/mi:kœrd/!?

(Hosseini, 2006)

However, during sacred war, a lot of symbols which were changed into national and epic ones entered the literature of Revolution. These symbols in some cases include names and places such as: Villages, plains, Strait, bridges and stations; names of warriors and politicians; theorists, commanders and soldiers; Brigade, battalion, and finally some operations, the war machinery and equipment such as backpacks, thermoses, trench or cultural signs like, bandanna, plaques:

/əlœhi:/ /bə/ /ıvızə/ /i:n/ /hœri:/ /bə/ /hu:rul/ /huvəyzə/ /bə/ /hu:rul/ /œzi:m/

/bə/ /dœfti:/ /kə/ /dœr/ /rœzm/, /œbıs/ $/ \mathrm{d} \Lambda \mathrm{st} /$

/kə/ /bi:/ /dœst/ /hœm/ /khəymə/ /rı/ $/ \mathrm{p} \Lambda \mathrm{s} / / \mathrm{d} \Lambda \mathrm{st} /$

/bə/ /məhrın/ /o/ /Jœrhıni:/ /o/ /mœrgə//su:r/

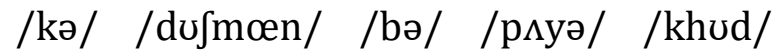
/ımœd/ /bə//gu:r/

/bə//fœthi:/ /kə/ /dœr/ /tœng/ /t〕ezzıbə//bu:d/

/zœbınə/ /hœmə/ /dufmœnun/ /lıbə/ /bu:d/

/bə/ /œzmi:/ /kə/ /ti:pə/ /hœvıburd/ $/ \mathrm{d} \Lambda \mathrm{ft} /$

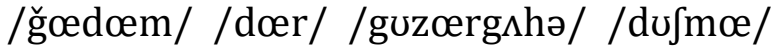
/guzs st/

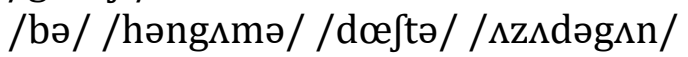

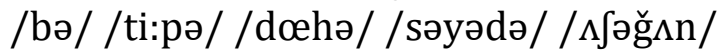

/bə/ /œzmi:/ /kə/ /dœr/ /lœfgœrə/ /hœmzə/ /bu:d/

/hœmırə/ /duru:də/ /hœmırə/ /suru:d/

/sə/ /rıhə/ /Jœhıdœt/ /pulə/ /khəybœri:/ /obu:r/ /œz/ /khœtœr/ /həmœtə/ /həydœri:/

(Beigi Habibabadi, 2009, p.212)

/bə/ /ının/ /kə/ /kıru:n//khuru:f/ / $\Lambda$ mœdœnd/

/hœmısə/ /hœmısə/ /bə/ /3u:f/ / $\Lambda$ mœdœnd/

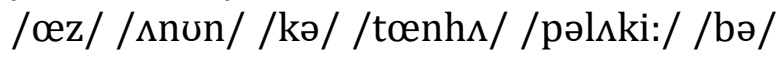
/3ıst/

/kœmi:/ /ustəkh $\Lambda$ / /muftə//khıki:/ /bə/ /3nst/

/kə/ /i:rın/ /hœm $\Lambda$ rə/ /sœrœfr $\Lambda \mathrm{z} /$ /b $\Lambda \mathrm{d} /$

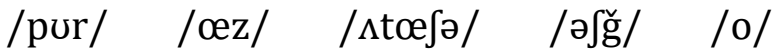
$/ \partial 3 \Lambda z / / b \Lambda d /$

(ibid. 207-8)

Even geographical directions and cities that are in the direction of these area changes through epic poet, literary and symbolic and - sometimes independently and sometimes conflict - are depicted as follows:

.../t $/$ (/sœd $\Lambda \mathrm{m} /) / \mathrm{mi}: m i: r i: /$

/o/ /3onu:b/

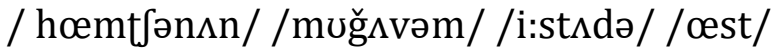

168)

(ibid,

$* * *$

... /bœzi:/ /bœryə/ /3œng/ /Junr/ /mi:dœhœnd/

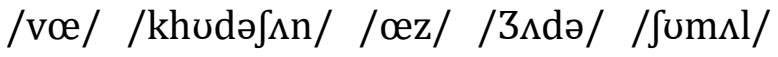
/bə/ /3əbhə/ /mi:rœvœnd/

(Ghazve, 2006)

It may be imagined that these names and symbols are short-lived and will be gone out of the realm of war history and literary field and will regain their past meaning and symbolism once upon a time. But by comparing the twenty five years after war and presence of names and symbols in poems of some poets which do not know anything about war except the names, we can make sure that these names 
decorated by symbols will play its role in poetry and literature of future.

\section{International Symbols}

One of the special features of poetry of revolution and war is the presence of foreigners and extra symbols in it. Before revolution and among the poems of materialist poet- which are mostly in left wings- referring to foreign elements, expressions do not surpass the phrases such as "neighbor house", "neighbor farm" and "over the walls" or the words which represent a special ideology such as "nation", "people" and " mass". However, by the beginning of Revolution and as a result of a deep thought process, a lot of foreign phenomenon entered the literature and poetry. These symbols were either chosen from Islamic countries such as Palestine, Lebanon, Dyer Yasin, Quds, Sinai, Gaze, Tur, and Gaze, soldiers, martyrs, children and homeless people, or from non-Islamic countries which have been under pressure of cruel systems before. Because of this, the poets wanted to overcome geographical, national, racial and even religious borders and scream "a shared pain". Such as:

/ţ//khu:b/ /bu:d/

/səpi:də/ /ni:z/ /mi:gri:st/

/tı//œz/ /bırə/ /delə/ /œbr/

$/ \Lambda \mathrm{g} \Lambda \mathrm{h} / / \mathrm{mi}: \int u d /$

/sœni:gi:ni:/ /tœmım/ /Јәnhıуә/ / $\Lambda$ fri:ğ $\Lambda /$

/dœr//tu:bœrə/ /rœnj/

/bœr/ /gurdə/ /mœn/ /œst/

Here, Lebanon, Palestine and all the symbols related to both are always a part of "special" international symbols of Revolution poetry: /3ınınә/ /mœn/ /œndu:h/ /lubnın/ /kuft/ / $\mathrm{m} \Lambda / / \mathrm{r} \Lambda /$

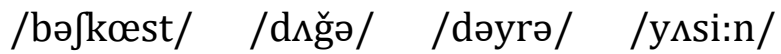
/puftə//m $\Lambda / / \mathrm{r} \Lambda /$

/3^nınə/ /mœn//bœrkhi:z/ /o/ /zi:n/ /bœr/ /b $\Lambda$ rgi:/ /nəh/

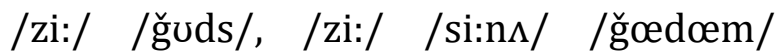
/yəkbムrəgi:/ /nə/

/bıyœd/ /zə/ /ılə/ /sıməri://kəyfœr/ /gərəftœe/

/mœrhœb/ /fəkœndœn/ /khəybœri:/ /di:gœr/ /gərəftœn/

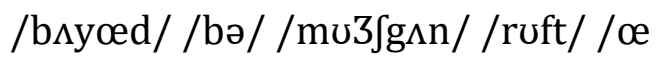

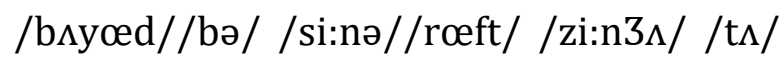
/fələsti:n/

(Sabzevari, 2009)

$* * *$

/khıhœrınə/

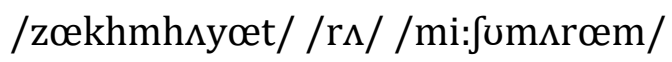

/œz/ / §œki:bi:œt/ /bi:ftør/ /ni:st/

/zəynœbə/ / $\mathrm{v} \Lambda$ rə/ /fləsti:n/!

/nımə/ /di:gœrœt/ /tii:st/

(Rakeiee, 2005, 38)

\section{Religious Symbols}

Another feature of poetry of Revolution and Sacred war period which separate it from poetry of before Revolution is thinking and content which is related to religious topics such as God, Prophecy, pontificate, leadership and second world. Islamic Revolution is integrated with policy due to its religious and political identity and has sufficient themes for creating similarities, metaphors, irony and collective symbols. The poets of revolution sometimes use common patterns of different religions such as Zoroastrianism, Christianity, Jewish and sometimes tend to use special symbols of Islam and Shia.

$141 \mid$ Page 
In this approach, the poet influenced by bipolar situation of history and conceptual aspect of this meaning in atmosphere of revolution show the symbols of these two poles in an opposite picture and illustrate the heroes and antiheroes of religious elements:

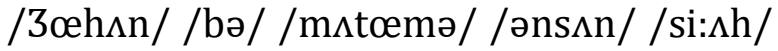
/pu:fi:də/ /œst/

/sœlœuə/ /œdl/ /zœn/ /0/ /dœst/

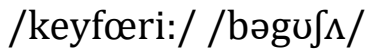

/tu/ /rı/ /kə/ /ğvdrœtə/ /bızu:уə/ /həydœri:/ /b $\Lambda$ jœd/

/ğœzœnfœrınə/ /bœrs $\Lambda \mathrm{u}: \mathrm{b} /$ /o/

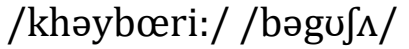

/dri:/ /bəro:yə/ /fəlsti:n/ /rœhi:/ /bəh/ /sahœtə//quds/

/bəh/ m'ejzh/ /bə/ /pœyami:/ /bə/ /lœshgœri:/ /bəgushaa/

(Sabzevari, 2009, p. 144)

/œz/ /rıh/ /rəsi:di:/

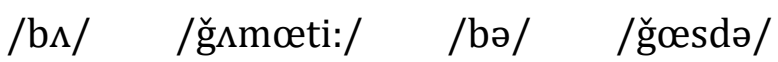
/ əkœestœn/

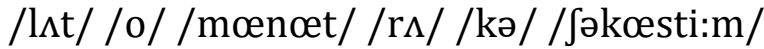

/œzzı/ /dəgœr/ /œzi:z/ /nəmi:mınœd/

/œz/ /rıh/ /rəsi:di:m/

/mi:rısə//bıstıni:/ /əbrıhi:m/

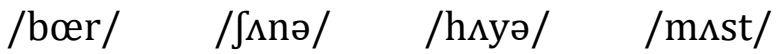

(Aminpour, 2011, p.373)

$* * *$

/ऽœmfi:ri:/ /kə/ /bœr/ /gœlui:/ /tu/ $/ \Lambda \mathrm{m} œ \mathrm{~d} /$

/hœrtfi:z/ /o/ /hœmətfi:z / /rs/ /dœr/ /knenst/

/bə/ /dv/ /pırə/ /kœrd/:

/hœrt i:z/ /dœr/ /su:yə/ /tu/ /huseyni:/ / $\mathrm{ud} /$

/vœ/ /di:gœr/ /su:/ /yœzi:di:/ /i:nœk/ /mıi:m/ /o/ /sœnghı/

/mıi:m/ /o/ / $\mathrm{bh} \Lambda /$

/dərœkhtın/, /ku:hsırın/. /ju:yb $\Lambda$ rın/,

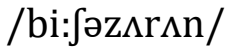

/kə/ /bœrkhi:/ /yœzi:di:/

/vœ/ /gœr/ /nœ/ /huseyni:œnd/ (Mousavi Garmaroudi, 2011, p.170)

\section{Philosophical and Mystic Symbols}

It seems that this saying of Barahani about Molana that: "Molavi is in part mystic and in part epic" is true (Barahani, 1992). At least form lingual and literary aspect, he can be among the poets of Revolution. As we have seen, the sacred war is a clear representation of epic, romance and mysticism and a combination of these concepts have surprised the authors:

/məhrbıni:/ /di:dəhi:/ /khi:zœd/ /zə/ /sœngəstın/

/du:stıri:/ /di:dəhi:/ /bılœd/ /zə/

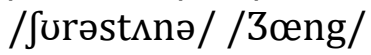

/gœr/ /nœdi:di:/ ənğəl $\Lambda \mathrm{b} /$ /m $\Lambda$ / /nəgœr/ /tı//bəngœri:/

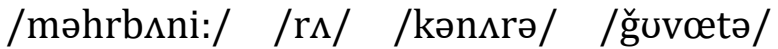
/bızu:/ /o/ /3œng/

(Mousavi Garmaroudi, 2010, p.69)

As the brevity accompanies by consciousness and sacrifices, martyrdom and brevity became two sides of a coin and paradox of epic and romanticism become common. Here is the place where "Coarseness" or "fineness" beautifully integrate and provide an interesting art for the reader or viewer.

In poetry of Revolution, symbols which have mystic meaning, as was mentioned by a famous person, symbols of "red death" and "purple death" are used for showing martyrdom. Or combinations and terms such as dancing without arms and legs, blooded hair and other replace the meaning: 
/mœn/ /vı3gu:n/ /mœn/ /vı3gu:n/ /mœn/ /vı3gu:n/ /rœğsi:dəœm/

/mœn/ /bi:/ /sœro/ /bi:/ /dœsto/ /ps/ /rœr/ /khıbə/ /khu:n/ /rœğsi:dəœm/

/mœnzu:mei:/ /œz/ / / tœJœm/

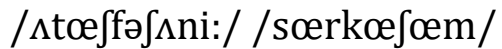

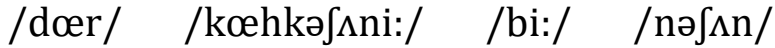
/khurfi:dgu:n/ /rœğsi:dəœm/

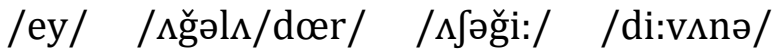
/mi:bıyœd/ /Judœn/

/mœn/ /b / /b;u:ğə/ /œğl/ /dœr/ o3/ /3unu:n/ /rœğsi:dəœm/

/mi:lıdə/ /d $\Lambda \mathrm{n} \Lambda \mathrm{i}: /$ /mœnœm/ /pœrv $\Lambda z ə /$ /bi:nıi:/ /mœnœm/

/mœn/ /dœr/ /oru:3i:/ /3ムvd $\Lambda$ n/ /œz/ /hœd/ /fuzu:n/ /rœğsi:dəœm/

/pi:rshœnə/ /tœn/ /psrə/ /kun/

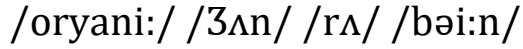

/mœn/ /dœr/ /3œhınə/ /di:gœri:/ /œz/ /khud/ /bru:n/ /rœğsi:dəœm/

/bı/ /rœğs/ /mœn/ /dœr/ / $\Lambda$ səmın/ /rœğs $\Lambda$ / /tœmımə/ /œkhtœrın/

/mœn/ /bœr/ bulœndıye/ /zœmın/, /bəngœr/ /kə/ /tuu:n/ /rœğsi:dəœm/

(Mardani, 1995, p.21)

Of course, sometimes philosophical and mystic symbols are used for praising a religious and political personality or for describing abstract concepts all over a poem:

/SCEb/ /kıfœr/ /Jud/ /dœr/ /sIshi:/ /bə//œğlə/ /surkh/ /sœr/ /zœd/ /S әуkhə/ /ə)rığ/

(Aminpour, 2011,p.457)

Or:

/hala/ /ru:zo/ /shab/ /fani:/ /Chashme/ tu/

/delam/ /shud/ /cheraghani:/ /chashme/ $/ \mathrm{tu} /$

/be/ /mehman/ /sharabe/ /atash/ /mi:dahad/

/shegeft/ /ast/ /mehmani:/ /chashme/ /tu/

/bana/ /ra/ bar/ /asle/ /khumari:/ /nahad/ /ze/ /ru:ze/ /azal/ /bani:/ /chashme/ $/ \mathrm{tu} /$

/pur/ /az/ /masmavi:haye/ /rendane/ /ast/

/shabe/ /sher/ /erfani:/ /chashme/ /tu/ /tui:/ /ghotbe/ /ru:hanie/ /jane/ /man/ /manam/ /saleke/ /fani:/ /chashme//tu/ /shafa/ /mi:dahad/ /ashkara/ /be/del/ /esharate/ /penhani:/ /chashme/ /tu/ (Hosseini, 2012, 36-7)

\section{Political and Revolutionary Symbols}

Political symbols since Mashroote movement up to now are widely used among the writers and authors of Iran, so that by using symbols and metaphors in a poem, we can give it a political perspective. In the poetry of before revolution, especially since 1332 , when political limitation was widely spread and people were fed up with cruelty, poetry and literature used symbols to cover the intended political meaning.

For example, when Nima and Shamlou or Ebtehaj used the left ideology keywords such as "neighbor" ( which represent Russia) or "mass" , "worker" and "laborer", it could be inferred that the related political pattern is a socialist type. Or if another poet such as Akhavan said that: “/næ/ /æz/ /rængæm/, /hæm $\Lambda$ / /bi:rængə/ /bi:rængæm/" and, in addition, emphasized on the names of Zardusht and Mani and Mazdak. It means that the poet did not belong to the political system of east or west and wishes of ancient times of Iran would come true. Furthermore, when another poet such as Safarzade ironically calls "old Kave" who is sleepy and cannot do anything else, it means that a horse will come from heavens and the Savor ends the years of tolerance.

After the revolution, the political symbolism of the poem continued to shine and with the difference that instead of using various ideological symbols which 
present plurality of political thoughts, symbols of unity of thoughts and political harmony would seize the poem and perform a harmonious symphony in literary and artistic atmosphere.

Political axis of poets in this period of time can be summarized in some general topics: fighting with West, especially America and supporting Palestinian and political thinkers who were against them.

West as the supporter of Iraq and main designer of the threats against new system of Islamic Republic was faced with attacks of poets as a negative symbol in poetry of the time.

The style of revolution poetry can be seen in denouncing America:

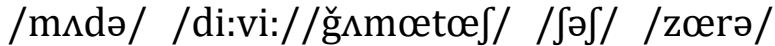
/o/ /si:sœd/ /pıy/ /t\}i:zi:/ /kœm/

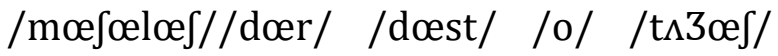
/bœr/ /sœr/ /œz/ /tırı3ə/ /mulkə//3œm/

(Moallem, 2010)

Zionist regime is also denounced because of occupying Palestine and killing Muslims. In contrast Palestine and the identities related to it were considered as positive and nice side of the coin. The poet of Revolution tried to motivate the feeling of Muslims and besiege them in fighting with the enemy and freeing Palestine:

/madara/ /kafan/ /mi:poushan/ /tuye/ /lubnan/

/bacheha/ /ba/ /mi:jangan/ /tu:/ /felesti:n/

/shomaha/ /ke/ /marde/ /jangi:n/ /shomaha/ /chera/ /neshasti:n/

/ay/ /delavaraie/ /ozbak/ /ay//bahadoraye/ /taji:k/

/vaedehai:/ /gharb/ /doroughe/ /cheshme/ /doore/ /darya nazdi:k/ /beyne/ /Gherghi:zi:o/ /turko/ /turkman/ /faseli:/ /ni:st/

/vase/ /hamdeli:/ /be/ /paie/ /tu/ /o/ /man/ /selseli:/ /ni:st/

/moslem/ /afghani:/ /o/ /irani:/ /o/ /kesh,i:ri:/ /nadare/

/tuye/ /donya/ /eyne/ /ma/ /omate/ /yekdelei:/ /ni:s/

/chera/ /khare/ /cheshme/ /ham/ /bashi:m/ /o/ /ysre/ /ham/ /nabashi:m/

/chers/ /baggh/ /ham/ /bahare/ /ham/ /nabashi:m/ (Moalleme Damghani, 2010)

Opponent political groups, artists and intellectuals of them, are other challenges for the poet of the revolution. The style of opponent politicians is usually imperative but aggressive.

Of course, sometimes, we see that the poet of revolution uses biting language in criticizing the opponents.

\section{Literary Symbols}

Symbols from every origin became a part of the language and poetry, as they entered, and can be called literary symbols. But we have to know that they have their own special meaning:

"Before imitating from other areas, they are born of creative mind of the poet and if they are loaned from another source, they will change based on condition and take a new form"

As it was said earlier, during the eightyear war, many symbols of the revolution entered in poetry and literature. Some of these symbols before reviving by literature had to meet the specific concepts and brought political, social and cultural rights.

The "sacred symbols" which are close to each other, form a chain of concepts and idealized picture of the historic atmosphere of the time. Some examples include: "Chafee" (fighters and partisans), 
"stronghold" (homes fighter), "barbed wire" (the suffering and hardships of Jihad), "Watch" (martyr), "wheelchair" (veterans), "Number" (missing), "red or green headband" (martyrdom and pilgrimage), "resolution 598 "(bitter peace) and many other noted.

None of the above examples - according to the characteristics of literary symbolsare the symbol of literary and poetic fail.

The literary symbols in the first instance should be made by the imagination of the poet or group of poets and other styles of thinking and like other sciences such as mythology, psychology, anthropology, folklore (folk), and the culture of war. They are not art unless they change the original meaning of the poet to symbolize change or at least overshadowed by the new concept.

/gurd/ / $\mathrm{f} œ r i: d /$ /to/ /fœğœt/ /œz/ /œsbœS/ /uft $\Lambda \mathrm{d} /$

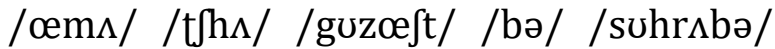
/ğœləgi:r/

In sum, in the holy realm of poetry and literary icons, we can say that; literary icons of this period are mainly Iraqi style and Hindi icons - particularly Hindi style: Symbols, such as water, rain, sea, ocean, drops, bubbles, sun (sun), bats, moon, shadow, flame, fire, flame, lights, candles, butterflies, tulips, poppies, cypress, trees, dawn, morning, stars, meteors, waterfalls, fountains, mist, ride, travel, road, eagles, vultures, pigeons and many other subtleties that poet uses remember the literary style of Esfahani or Hindi poetry: /œgœr/ /œz/ /kœbu:tœr/ /nœgu:yœm/ /sukhœn/

/mœrs/ /khu:nə/ /pœrvsz//bœr/ /gœrdœn/ /œst/

(Beigi Habib Abadi, 2009, 206)

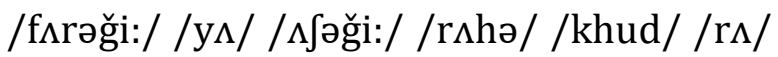
/bugzi:n/ /gœr/ /Jœrıri:/ /bœrkhi:z/ /vœr/ /ğubıri:/ /bənfi:n/

(Moallem Damghani, 2010)

However, there are some out of reach images which are byproducts of poets' imagination in literature of revolution:

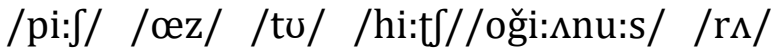

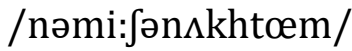

/kə//œmu:d/ /bœrzœmi:n/ /bəi:stœd/

(Mousavi Garmaroudi, 2011)

/hœvıуә/ğәуr/ /bru:n/ /kun/ /zə/ /sœr/ /kə/ /bi:/ /ğœdr/ /œst/

/hubıb/ /kœz/ /nœfœsə/ /di:gœri:/ /hœvs/ /gi:rœd/

/hœr/ /ınkə/ /sığœrœf/ /œz/ /Jœhd/

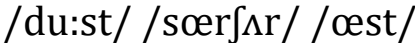

/ œœrœng/ /œz/ /kœfə/ /bi:gunəg $\Lambda$ / /tərı/ /gi:rœd/

(Sabzevari, 2009)

/zə/ /ムn/ /dœst/ /kə/ /tكun/ /pœrœndə/ /bi:t $\Lambda$ b/ /oft $\Lambda$ d/

/bœr/ /sœth/ /kərəkht/ / $\mathrm{bhh} \Lambda /$ /t $\Lambda \mathrm{b} /$ /oft $\Lambda$ d/

/dœst/ /to/ /tfo/ /ru:d/ /tı/ /œbœd/ /3ıri:/ /Jud/

/zın/ /ru:I/ /kə/ /dœr/ /həmıyœt/ /œz/ / $\mathrm{b}$ / /oft $\Lambda$ d/ (Harati, 1997)

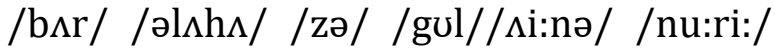
/bəfrəst/

/ku:r/ /fud/ /sərmə/ /œndi:fə/ /zuhu:ri/ /bəfrəst/ (Azizi, 1992)

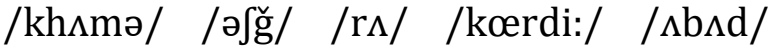
/dœstə/ /tœsvi:rhıyœt/ /mœri:zıd/

(Kakaie, 1990)

\section{Conclusion}

Contrary to the belief of some critics that the lyrics are not so powerful in terms of technique after the Islamic Revolution, the present study- in brief - illustrated that the poetry of this period, and particularly sacred war poetry, particularly the use of 
the literary "symbols" is a surprisingly artistic effects.

The poets of Revolution, unlike the orators before the uprising of 1357, not only use the national and literary symbol, but due to the nature and objectives of the revolution, use more of religious and mystical symbols.

Poets such as Hamid Sabzevari, Moallem, Ali Mousavi Garmaroudi, with an artistic combination of mythological symbols and patterns, have revived the sonnets of Khorasani style.

Seyed Hasan Hosseini, Gheysar Aminpour, Abdul Jabbar Kakaiee, Ghader Tahmasebi and other young poets of our time have shown greater tendency toward literary and mystical symbols by focusing on the affective and emotional aspects of the war.

Flights of imagination in poetry of poets such as Ahmad Azizi and his use of literary symbolism and poetry is stunning and a poet like Seyyed Hassan Hosseini has used various symbols even with archetypes viable method for humor and social and cultural criticism.

\section{References}

Akbari, M. (1992). Analysis and Criticism of Revolution Literature. Organization of Islamic Document. Tehran.

Akhavansales, M. (2007). After Thunder. Sokhan, Tehran. $4^{\text {th }}$ edition.

Aminpour, Gh. (2011). Poets. Morvarid Press, Tehran.

Azizi, A. (1992). Rain of butterflies, Barg. Tehran.

Bahmani, M. (2011). Poets. Negah, Tehran.

Bakhshude, H. (2005). Symbolism in Blank poetry of war. Keyhan, n.233.
Beigihabibabadi, P (2009). Third chapter, Teka, Tehran, $3^{\text {rd }}$ edition.

Dad, s. (2008). Literary terms, Mourvari:d, $4^{\text {th }}$ ed.

Ghazve, A. (2006).Andimesh train, 2nd edition.

Harati, S. (1998). From green sky. Art association.

Hosseini, S.H (2012). Calling by Esmail. Soure Mehr, Tehran, $6^{\text {th }}$ ed.

Hosseini, S.H., (2008). Generic design remedy. Soure Mehr, Tehran, $7^{\text {th }}$ ed.

Kakaiee, A. (2000). Mourning of Soul. Art association, Tehran.

Kakaiee, A. (2006). Songs of red generation (modern poetry of Iran). Urooj, $2^{\text {nd }}$ ed., Tehran

Makaremi nia, A. (2005). Sacred war poetry. Tarfand, Tehran, 2 ed.

Mardani, N. (1995). Thunder horse. Art association, Tehran.

Mirsadeghi, J. (2001). Elements of story. Sokhan, $4^{\text {th }}$ ed. Tehran.

Moallem Damghani, M (2010). Bits of voice inwind. Soure Mehr, Tehran.

Mousavi Garmaroudi, A., (2010). Olive union on bergamot branch. Souremehr, Tehran.

Mousavi Garmaroudi, A., (2010). Purple Sleep, Souremehr, Tehran.

Mousavi Garmaroudi, A., (2010). Earrings of Heaven. Souremehr, Tehran.

Rakeiee, F. (2005). Like Mothers. Etelaat, Tehran, $2^{\text {nd }}$ ed. 
Sabzevari, H. (2009). Another poetry. Ghalam Associate. Tehran

Sabzevari, H. (2009). Blank poetry. Ghalam Associate. Tehran.

Safarzade, T. (2005). Fifth trip.Pars ketab, Tehran.

Saye, H. (1990). mirror in mirror. By Shafiee kadkani, Cheshme, Tehran.
Shamis, S. (1994). Bayan, Ferdous. Tehran. $4^{\text {th }}$ edition.

Shanloo, A. (2004). Pieces, $1^{\text {st }}$ volume. Poems, Negah, $5^{\text {th }}$.tehran.

Yushij, N. (1998). Poems. Supervised by Sharagim Yushij. Eshare. Tehran.

How to cite this article: Hojjatollah.ghe.Moniri, Nushin Dohniyatkar, Symbol and Symbolism in Sacred Poetry. International Journal of Advanced Studies in Humanities $\begin{array}{llll}\text { and Social } \quad \text { Science, } & \text { 137-147. }\end{array}$

http://www.ijashssjournal.com/article 84352.html 